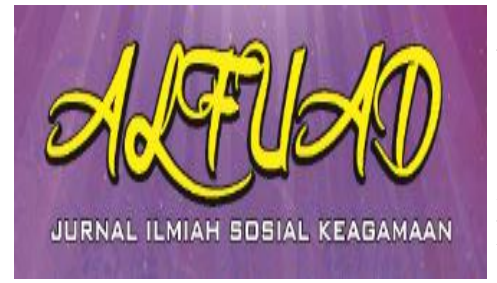

ALFUAD JOURNAL, 4 (1), 2020, (12-24)

(E-ISSN 2714-7606 P-ISSN 2614-4786 )

Available online at

http://ecampus.iainbatusangkar.ac.id/ojs/index.php/alfuad

\title{
STRATEGI PERPUSTAKAAN MENERAPKAN LITERASI UNTUK MENINGKATKAN IMAJINASI, KREATIVITAS, INOVASI
}

\author{
Laksmi \\ Universitas Indonesia \\ E-mail: $\underline{\text { laksmi@ui.ac.id }}$
}

\begin{abstract}
This research discusses the library strategy of applying literacy to increase imagination, creativity and innovation. Various libraries carry out various literacy programs, including GLN and GLS. However, the results have not looked encouraging. UNESCO in 2017 stated that out of a total of 61 countries, Indonesia ranked 60th at a low literacy level. Literacy activities, namely activities that empower the movement of reading and writing, can make someone create imagination, creativity, and innovation. Libraries must have effective and efficient literacy implementation strategies, based on 6 types of literacy, namely literacy, numeracy literacy, scientific literacy, ICT literacy, financial literacy, and cultural and citizenship literacy. Librarians need to pay attention to the process of developing literacy, namely: text and facilities; literacy type and purpose, learning context, and learner character. Librarians determine the competencies to be achieved, then determine the quality of character and type of literacy. In the application process, librarians introduce methods of reading books and storytelling, creating a safe and pleasant atmosphere, letting users experiment, and playing roles.
\end{abstract}

Kata kunci: Literacy Movement, Imagination, Creativity, Innovation

\section{PENDAHULUAN}

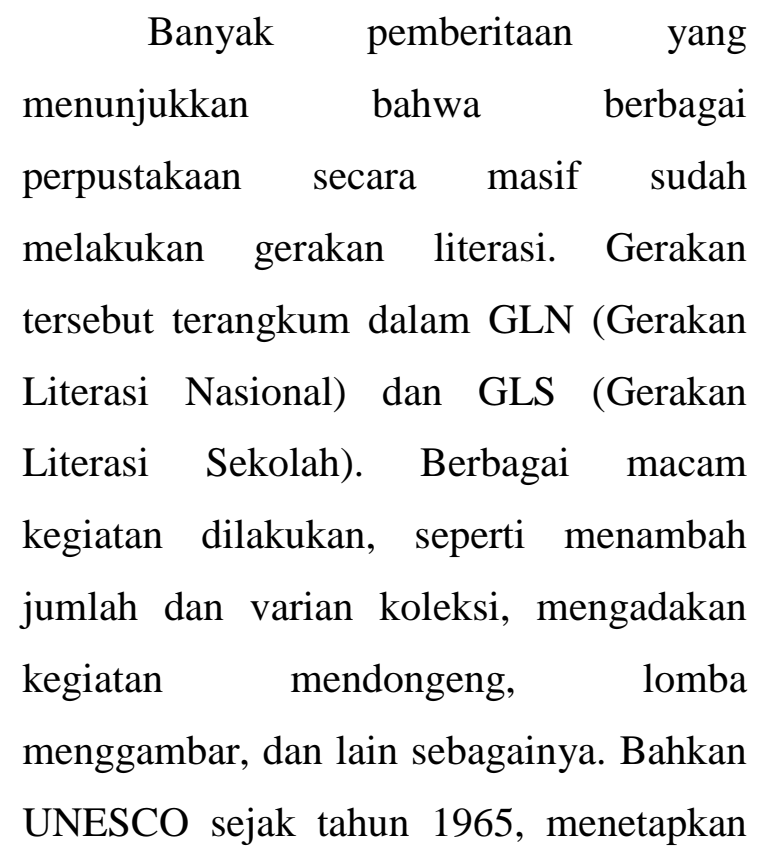

Hari Literasi Internasional pada setiap tanggal 8 September. Dengan berbagai kegiatan tersebut, bagaimana peningkatan literasi di masyarakat? Apakah masyarakat menjadi gemar membaca? Apakah mereka memahami isi bacaan? Selain itu, bagaimana dengan agen penggerak literasi, bagaimana dengan literasi mereka? Pertanyaan-pertanyaan tersebut sebaiknya dikembalikan pada konsep, apa tujuan gerakan literasi dan bagaimana metode yang sesuai dengan budaya masyarakat Indonesia? 
Gerakan literasi perlu dilakukan sebab sebagian besar penelitian menunjukkan bahwa terdapat hubungan antara literasi dan intelektualitas (MinYing, 2015; Permatasari, 2014: 14). Individu yang berliterat mampu menciptakan imajinasi, kreativitas, dan akhirnya menciptakan inovasi. Artinya, seseorang yang memiliki kemampuan membaca dan menulis, ia akan memiliki imajinasi yang kuat. Individu yang memiliki imajinasi akan mampu menciptakan sesuatu yang berbeda dari yang sebelumnya atau yang belum pernah terbayangkan oleh yang lain. Namun meskipun gerakan literasi sudah banyak dilakukan, faktanya masyarakat, khususnya anak-anak, belum memiliki literasi yang memadai. Berdasarkan hasil riset UNESCO tahun 2017, dari total 61 negara, Indonesia berada di peringkat 60 dengan tingkat literasi rendah di bawah Thailand dan di atas Botswana (Iswari, 2017: 22). Peringkat nomor 1 dengan tingkat literasi tinggi adalah Finlandia.

Dalam konteks ini, agen penggerak literasi yaitu pustakawan atau tenaga perpustakaan, perlu dipertanyakan metode mereka dalam menumbuhkan imajinasi dan kreativitas pemustaka, baik pada anak maupun dewasa. Staf dalam suatu organisasi harus memiliki profesionalisme, yang salah satunya ditunjukkan dengan kemampuan literasi yang dapat menumbuhkan kemampuan imajinasi dan kreativitas (Thompson, 2018: 42). Berdasarkan penelitian Wicaksono (2016), literasi pustakawan di perpustakaan khusus dan perpustakaan perguruan tinggi mempunyai kemampuan literasi informasi yang tergolong cakap, hingga mencapai tingkat mahir. Sementara itu, tenaga perpustakaan di perpustakaan sekolah yang umumnya dilaksanakan oleh guru pustakawan dan di perpustakaan umum yang dikoordinasi oleh masyarakat yang peduli dengan literasi, belum ada penelitian yang meneliti hal itu. Bisa jadi mereka juga memiliki literasi tinggi, atau sebaliknya.

Namun demikian, gerakan literasi ini bukan hanya membutuhkan pustakawan yang berliterasi tinggi, tetapi juga membutuhkan kemampuan dalam menerapkan literasi, sebagai praktik sosial, untuk dapat menumbuhkan imajinasi dan kreativitas pada pemustaka anak dan dewasa. Proses literasi adalah proses belajar, yang merupakan kegiatan utama masyarakat informasi atau masyarakat berbasis pengetahuan (Vulkasinovic, 2014: 9).

\section{METODE}

Adapun metode penelitian kajian pustaka atau studi kepustakaan yaitu berisi teori teori yang relevan dengan masalah masalah penelitian. Pada bagian ini 
dilakukan pengkajian mengenai konsep dan teori yang digunakan berdasarkan literatur yang tersedia, terutama dari artikel-artikel yang dipublikasikan dalam berbagai jurnal ilmiah. Kajian pustaka berfungsi untuk membangun konsep atau teori yang menjadi dasar studi dalam penelitian. Kajian pustaka atau studi pustaka merupakan kegiatan yang diwajibkan dalam penelitian, khususnya penelitian akademik yang tujuan utamanya adalah mengembangkan aspek teoritis maupun aspek manfaat praktis. Sehingga dengan menggunakan metode penelitian ini penulis dapat dengan mudah menyelesaikan masalah yang hendak diteliti (Sujarweni, 2014 :33).

\section{HASIL DAN PEMBAHASAN}

\section{Literasi dan manfaatnya}

Method Literasi umumnya dipahami dalam dua pengertian yang berbeda. Menurut IFLA, pengertian literasi yang pertama adalah kemampuan individu untuk menggunakan potensinya dalam mengolah dan memahami informasi. Pengertian kedua, literasi dipahami sebagai kegiatan dalam memberdayakan gerakan membaca dan menulis. Perpustakaan menamai kegiatan tersebut sebagai pendidikan pemakai.

Dalam pengertian pertama, pembahasan biasanya menekankan tingkat kemampuan seseorang dalam mengelola informasi dan bagaimana ia memperoleh kemampuan tersebut. Sementara itu pada pengertian literasi sebagai pendidikan pemakai, umumnya pembahasan lebih menekankan pada metode atau strategi individu atau perpustakaan menanamkan kemampuan literasi pada seseorang. Dalam konteks ini, pengertian literasi menekankan pada pengertian yang kedua, yaitu strategi perpustakaan dalam meningkatkan kemampuan literasi pada masyarakat. Memiliki literasi merupakan sesuatu yang penting, sebab seseorang yang mampu menangkap dan memahami informasi, ia dapat melihat fenomena secara lebih kritis. Pemahaman tersebut akan membimbingnya dalam menghadapi masalah kehidupan.

Dapat disimpulkan bahwa keberliterasian bukan hanya masalah bagaimana suatu bangsa bebas dari buta aksara, melainkan juga yang lebih penting, bagaimana suatu bangsa memiliki kecakapan hidup agar mampu bersaing dan bersanding dengan bangsa lain untuk menciptakan kesejahteraan dunia. Dengan kata lain, bangsa dengan budaya literasi tinggi menunjukkan kemampuan bangsa tersebut dalam berkolaborasi, berpikir kritis, kreatif, komunikatif sehingga dapat memenangi persaingan global.

Kemampuan literasi yang tinggi dapat dikatakan sebagai budaya baca yang tinggi. Namun demikian, tidak berarti 
bahwa mereka yang memiliki budaya baca yang lebih kental daripada budaya lisan lebih baik daripada mereka yang memiliki budaya lisannya lebih tinggi. Kedua budaya tidak dapat dipertentangkan, sebab kedua memiliki karakter yang berbeda. Apabila keduanya bersinergi dan seimbang, maka masyarakat akan menghasilkan perilaku terbaik yang mampu mengatasi permasalahan kehidupan dengan lebih baik.

\section{Berdasarkan ACRL (American}

College and Research Libraries), individu yang memiliki kemampuan literasi mendapatkan manfaat sebagai berikut: mampu menentukan sifat dan tingkat informasi yang dibutuhkan; mampu mengakses informasi yang dibutuhkan secara efektif dan efisien; mampu mengevaluasi informasi dan sumbernya secara kritis; mampu mengintegrasikan informasi yang dipilih ke dalam pengetahuan mereka; mampu menggunakan informasi secara efektif untuk mencapai tujuan tertentu; dan mampu memahami masalah ekonomi, hukum, dan sosial yang melingkupi penggunaan informasi, dan menggunakan informasi secara etis dan legal (American Library Association, 2009: 16).

\section{Literasi meningkatkan majinasi, kreativitas, inovasi}

Kegiatan literasi yang dilakukan dapat membuat seseorang menciptakan imajinasi, kreativitas, dan inovasi. Pengertian imajinasi adalah daya pikir untuk membayangkan atau menciptakan gambar-gambar di dalam pikiran, berdasarkan kenyataan atau pengalaman seseorang. Gambaran tersebut dapat juga disebut sebagai khayalan. Anak-anak di bawah usia 7 tahun dengan pola pikir yang masih apa adanya seringkali melakukan imajinasi. Mereka memiliki kemampuan melakukan fantasi. Pada dasarnya, setiap individu memiliki kemampuan berimajinasi, meskipun kadarnya berbedabeda.

Imajinasi dapat dikembangkan dengan memberikan stimulasi atau dorongan untuk melakukan imajinasi. Pemberian stimulasi dapat dilakukan secara lisan atau bercakap-cakap atau dengan menggunakan sarana, seperti buku, alat menggambar, boneka, balok kayu, dan sejenisnya. Melalui percakapan, individu bertukar pikiran, sehingga masing-masing dapat saling membuat sebanyak mungkin ide. Pada saat seseorang membaca, menggambar, atau bermain dengan alatalat tertentu, ia membuat asosiasi di dalam pikirannya. Ketika sesorang membaca kata 'perpustakaan', pikirannya akan memunculkan sebuah imajinasi, misalnya 
ia langsung membayangkan ruangan besar yang dipenuhi dengan rak dengan bukubuku berjejer rapi; atau membayangkan orang-orang yang sedang membaca buku atau bercakap-cakap dengan buku di tangan, duduk di sofa di sebuah kafe. Imajinasinya tergantung pada pengalamannya atau bacaan yang pernah dibacanya. Imajinasi yang kuat mampu menciptakan kreativitas.

Kreativitas adalah kemampuan untuk menciptakan sesuatu yang baru, baik berupa gagasan baru maupun suatu temuan baru. Setiap orang memiliki kreativitas yang berbeda-beda, dan masing-masing dapat mengembangkan dan meningkatkannya. Dalam era globalisasi yang ditandai dengan perubahan yang cepat dalam segala aspek kehidupan, kreativitas merupakan suatu kekuatan yang dapat dimanfaatkan dalam persaingan yang ketat. Bila seseorang atau suatu lembaga tidak memiliki kreativitas, ia akan terimbas oleh mereka yang mampu menciptakan sesuatu yang berbeda dari yang lain.

Seseorang yang kreatif biasanya memiliki dorongan yang tinggi dan memiliki kepedulian terhadap lingkungan yang tinggi. Ia juga memiliki keingintahuan, tekun, selalu ingin meningkatkan kemampuan, percaya diri, memiliki kemandirian, bebas dalam mengambil keputusan, menerima diri apa adanya, senang humor, memiliki intuisi, tertarik kepada hal-hal yang komplek, toleran, dan sensitif terhadap lingkungan. Kreativitas dipengaruhi oleh interaksi seseorang dengan lingkungannya, baik dengan manusia maupun lingkungan. Kognitif individu selalu mempertanyakan secara kritis segala sesuatu yang dapat ditangkap pancaindera untuk ditingkatkan, sehingga menciptakan sesuatu yang baru atau inovasi. Inovasi, yang dapat berbentuk gagasan maupun sesuatu, merupakan hal yang dianggap baru. Inovasi yang dimanfaatkan dalam kurun waktu lama, lambat laun akan dianggap biasa dan tidak dianggap sebagai sesuatu yang inovatif lagi. Perkembangan teknologi dan gaya hidup masyarakat yang dinamis akan selalu menciptakan inovasi-inovasi yang berbeda.

Hubungan antara imajinasi, kreativitas, dan inovasi akan berjalan dalam siklus. Imajinasi melihat hal-hal yang tidak mungkin, yang kemudian didorong oleh kreativitas yang berupaya untuk mewujudkan gagasan yang tidak mungkin tersebut, yang belum terpikirkan oleh yang lain, menjadi sesuatu yang mungkin terjadi. Upaya tersebut menciptakan inovasi. Semakin tinggi daya imajinasi seseorang, semakin tinggi kreativitasnya. Keduanya memiliki hubungan timbal balik. Semakin tinggi kreativitas, akan semakin tinggi pula penemuan-penemuan baru atau inovasi 
yang diciptakannya. Inovasi-inovasi tersebut akan mendorong kreativitas lebih aktif lagi, sehingga menstimulasi imajinasi untuk lebih berkembang.

\section{Perpustakaan dan penerapan literasi Mengajarkan literasi}

Untuk menerapkan literasi, berbagai perpustakaan melakukan kegiatan yang variatif. Mulai dari menyediakan berbagai jenis bacaan, mengadakan kegiatan mendongeng secara rutin, mengadakan lomba menulis, mengadakan layanan nonton bersama, layanan perpustakaan keliling, hingga mendekorasi ruang perpustakaan yang menarik. Rangkaian kegiatan yang dilakukan tersebut merupakan penerapan literasi yang dilakukan secara kreatif. Penerapan tersebut bisa saja menghasilkan perilaku gemar membaca, tetapi belum tentu dapat menciptakan kemampuan berimajinasi dan kreativitas (Syaodih, 2015: 17)

Berdasarkan pemikiran Jeffry dan Craft, mengajar secara kreatif dan mengajarkan kreativitas adalah dua hal yang berbeda (Jeff rey \& Craft, 2004: 20). Mengajar secara kreatif menekankan metode mengajar yang efektif dan bervariasi. Pengajar dituntut untuk memliki imajinasi dan kreativitas saat memberikan pengetahuan. Sementara itu, mengajarkan kreativitas lebih berorientasi pada pemustaka, baik anak maupun dewasa, menekankan metode agar pemustaka menjadi imajinatif dan kreatif. Pengajaran ini membutuhkan interaksi yang dilakukan secara intensif dan rinci, yaitu dengan memperhatikan latar belakang dan karakter setiap pemustaka, perubahan perilaku, kemampuan menerima pengetahuan, atau respon dan reaksi pemustaka. Salah satu interaksi adalah melalui komunikasi dua arah, bermain peran, Interaksi yang tepat pada anak, misalnya, adalah interaksi yang menyenangkan dan membahagiakan, merupakan pembuka jalan untuk menanamkan nilai dan mendorong munculnya imajinasi dan kreativitas.

\section{Strategi perpustakaan menerapkan literasi}

Beberapa pakar menjabarkan jenis literasi yang berbeda-beda. Berdasarkan kesepakatan World Economic Forum yang berkomitmen untuk meningkatkan kualitas Negara-negara di dunia, tahun 2015, jenis literasi dasar terdiri dari 6, yaitu (World Economic Forum, 2015): (1) Literasi (literacy). Kemampuan ini merupakan kemampuan paling utama, yaitu mampu membaca dengan memahami isi teks yang dibaca, yang terdiri dari kata, simbol, angka, atau grafik. Masyarakat lisan yang memiliki kecenderungan untuk lebih banyak berbicara, melihat, dan mendengar, pandai menghafal, meniru, dan bermain 
kata (seperti berbalas pantun), tetapi kurang mampu memahami bacaan teks.

(2) Literasi numerasi (numeracy). Literasi jenis ini merupakan kemampuan dalam menggunakan berbagai macam angka dan simbol-simbol yang terkait dengan matematika dasar untuk memecahkan masalah praktis dalam konteks kehidupan sehari-hari dan kemampuan menganalisis informasi berupa grafik, tabel, bagan, dan sebagainya. Misalnya, individu mampu memilih bentuk grafik, bila menggunakan grafik batang ia bertujuan untuk memperlihatkan perbedaan tingkat nilai dari beberapa aspek pada suatu objek, sedangkan jika ia menggunakan grafik garis, ia bertujuan menggambarkan suatu perkembangan atau perubahan dari waktu ke waktu pada sebuah objek. Kemampuan ini juga mencakup kemampuan menginterpretasi data untuk membuat prediksi atau mengambil suatu keputusan.

(3) Literasi sains (scientific literacy). Literasi jenis ini adalah kemampuan menggunakan sains, mengidentifikasi pertanyaan, dan menarik kesimpulan berdasarkan bukti-bukti untuk mendapatkan penjelasan atau pemahaman ilmiah dalam upaya membuat keputusan berkenaan atau perubahan berkaitan dengan alam. Literasi sains terdiri dari empat domain yaitu domain konteks, kompetensi sains, pengetahuan sains, dan sikap terhadap sains. Domain literasi sains mencakup konsep sains, yang terkait dengan isu personal, lokal, nasional, dan global. Domain kompetensi sains adalah menjelaskan fenomena ilmiah, mengevaluasi dan merancang penelitian ilmiah, serta menginterpretasikan data dan bukti ilmiah. Domain pengetahuan sains adalah mencakup konten materi sains, pengetahuan prosedural, seperti observasi atau mengukur data, dan pengetahuan epistemik, yang berkaitan dengan kemampuan merumuskan penjelasan ilmiah dan menemukan solusi. Domain sikap terhadap sains berkaitan dengan minat terhadap pengetahuan dan teknologi, kesadaran lingkungan dan menentukan pendekatan ilmiah yang sesuai dengan fenomena. (4) Literasi TIK (ICT literacy). Literasi teknologi informasi dan komunikasi atau disebut juga dengan literasi digital adalah kemampuan untuk mengakses, memahami, menggunakan, dan menyebarkan informasi dalam berbagai bentuk dan sumber yang diakses melalui berbagai aplikasi dan jaringan, seperti web, e-mail, Facebook, twitter, dan lain sebagainya. Penggunaan literasi ini juga terkait kemampuan memahami etika berinteraksi di dalam masyarakat virtual, baik yang tertuang di dalam UU ITE maupun norma-norma tidak tertulis, (5) Literasi keuangan (financial literacy). Literasi keuangan adalah kemampuan untuk menggunakan uang secara efisien 
dan efektif, mencakup cara memperoleh, menyimpan, membelanjakan, dan menyumbangkan uang (Kementerian Pendidikan dan Kebudayaan, 2017). Literasi keuangan ini dibutuhkan untuk memberikan pemahaman dasar kepada pemustaka, terutama anak, mengenai pentingnya nilai uang, dengan demikian anak-anak mampu membuat keputusan finansial untuk menyelesaikan masalah kehidupan. Banyak yang masih berpikir bahwa anak diajarkan masalah keuangan pada usia dewasa dan banyak juga kebiasaan organisasi yang tidak transparan dalam keuangan (Rapih, 2016). Sebaiknya sejak kecil, anak harus dilibatkan dalam masalah keuangan. (6) Literasi budaya dan kewarganegaraan (cultural and civic literacy). Kemampuan ini mencakup memahami dan bersikap terhadap kebudayaan, contohnya kebudayaan Indonesia sebagai identitas bangsa, temasuk memahami multikultural, sedangkan literasi kewarganegaraan adalah kemampuan dalam memahami hak dan kewajiban sebagai warga Negara. Di masa globalisasi ini, masyarakat tidak hanya harus memiliki kemampuan untuk memahami suku bangsa, bahasa, kebiasaaan, adat istiadat, kepercayaan, dan lapisan sosial yang beragam, tetapi juga harus mampu beradaptasi dengan perkembangan dan perubahan global, serta bersikap dalam masyarakat internasional.
Pustakawan sebagai Kunci Literasi

Perpustakaan umum dan perpustakaan sekolah merupakan dua jenis perpustakaan yang banyak berhubungan dengan anak-anak. Kedua jenis perpustakaan tersebut merupakan lembaga yang strategis untuk mengembangkan sumber daya manusia yang unggul, sebab dapat membentuk penggunanya yang di usia kanak-kanak. Upaya tersebut tentunya memerlukan sejumlah tenaga perpustakaan yang tidak sedikit dan juga kemampuan tertentu. Bahkan meskipun perpustakaan sekolah yang pada dasarnya menjalankan proses pembelajaran, perpustakaannya perlu terlebih dahulu menumbuhkan literasi pada diri tenaga perpustakaan atau guru pustakawan (Chowdhury, 2008: 18).

Tenaga perpustakaan yang berliterasi unggul, yaitu yang dapat menerapkan literasi pada pengguna yang masih sulit ditemukan di perpustakaan di Indonesia. Kebanyakan mereka lebih cenderung disibukkan oleh rutinitas pekerjaan sehari-hari dibandingkan menerapkan literasi pada penggunanya. Pustakawan perlu mengubah metode kerjanya menjadi lebih proaktif. Hernelahti dan Kolehmainen menyatakan bahwa pustakawan di kota Turku, pantai baratdaya Finlandia, harus mengubah kinerja mereka "dari duduk dan menunggu menjadi berjalan dan berbincang-bincang" (Hernelahti \& Kolehmainen, 2014: 65). 
Artinya, pustakawan di unit layanan tidak lagi hanya duduk dan menunggu pemustaka datang mencari mereka, tetapi mereka lah yang harus aktif berjalan menghampiri pemustaka dan mengajak mereka mengobrol.

Perpustakaan perlu meningkatkan literasi para pustakawan. Menurut Wicaksono, kemampuan literasi pustakawan dipengaruhi oleh faktor internal yang mencakup motivasi, sikap terhadap profesi, latar belakang dan strata pendidikan (Wicaksono, 2016: 20). Kemampuan tersebut pertama-tama didorong oleh motivasi dari dalam diri pustakawan, yang kemudian menggerakkan perilakunya untuk memiliki literasi. Sikap terhadap profesi, seperti rasa bangga dan percaya diri, ditambah dengan pendidikan di bidang yang relevan, dapat mendorong keinginannya untuk meningkatkan literasi. Selain itu, faktor eksternal yang mempengaruhi kemampuan literasi pustakawan adalah tersedianya komputer dan jaringan internet, dan kebijakan lembaga induk yang mendukung pengembangan kompetensi literasi informasi. Fasilitias yang memadai dan dukungan lembaga sangat membantu pustakawan meningkatkan literasi.

Selain ketersediaan koleksi buku, fasilitas yang perlu disediakan adalah sarana permainan, alat peraga, perangkat multimedia, dekorasi yang menarik.
Kebijakan organisasi juga harus berorientasi pada literasi pustakawan dengan mengadakan pelatihan, serta mewajibkan mereka membaca dan memahami koleksi yang ada di perpustakaan, dan mengamati fenomena yang berlangsung (Thompson, 2018: 20). Bagi perpustakaan yang sudah siap, yaitu yang memiliki tenaga perpustakaan dan fasilitas yang memadai, dapat menerapkan literasi yang harus dilakukan secara kreatif, sehingga dapat menumbuhkan imajinasi dan kreativitas pada pemustaka anak dan dewasa.

\section{Langkah-Langkah yang Perlu Diperhatikan}

Untuk meningkatkan imajinasi, kreativitas, dan inovasi, penerapan literasi membutuhkan perencanaan yang matang. Terdapat 4 komponen dalam membangun praktik literasi, yaitu (Council, 2012; World Economic Forum, 2015): (1) Teks dan sarana. Teks dipilih dengan yang dapat memberikan tantangan, bermakna, dan menarik, yang memungkinkan anak dapat mempraktikkan keterampilan melek komponen, dengan tingkat kesulitan yang sesuai. Sarana yang dimaksud adalah berbagai macam media, baik cetak maupun elektronik, yang dapat menstimulasi mereka untuk membaca dan menulis. (2) Kegiatan dan tujuan literasi. Kegiatan literasi, seperti menyusun tulisan, membuat portal, merancang kemas ulang, melakukan 
penghijauan lingkungan, dan sebagainya, memiliki tujuan tertentu dan menghasilkan kemampuan tertentu sesuai dengan jenis literasi. Apabila perpustakaan hanya menyediakan koleksi dan berharap pemustaka akan membacanya, pemustaka yang memiliki kemauan atau kebiasaan untuk membaca, dapat berhasil mencapai tujuan. Namun jika pemustaka belum berbudaya baca, kemungkinan besar mereka tidak akan menyentuh buku-buku yang disediakan di rak, sehingga tujuan yang diharapkan tidak tercapai. Pengalaman merasakan dan melakukan sangat berperan mendorong imajinasi dan kreativitas.

Kegiatan literasi juga harus diupayakan bukan untuk kegiatan yang hanya sesaat, tetapi dapat dilakukan secara berkelanjutan (lifelong learning). Kegiatan literasi yang mengajarkan kemampuan menulis membutuhkan latihan yang terusmenerus dalam kurun waktu yang tidak dapat ditentukan dan membutuhkan kesabaran serta ketekunan. (3) Konteks pembelajaran. Konteks merupakan proses yang melibatkan manajemen lembaga induk, pustakawan, dan pemustaka, yang saling berkolaborasi membangun budaya literasi. Selain dukungan lembaga induk, pustakawan juga harus memahami jenis literasi dan kompetensi yang akan dihasilkan, termasuk memahami karakter pemustaka, baik anak maupun dewasa.
Interaksi di antara keduanya perlu dibangun berdasarkan keyakinan, norma, dan nilai yang sesuai (Prinsloo, 2013: 11). Pustakawan harus mampu membangun rasa saling percaya dengan pemustaka, serta membangun pengalaman baru yang menyenangkan, yang membuat pemustaka akan mudah menerima instruksi dan motivasi yang diberikan (Varheim, 2014: 27). Pelibatan tersebut, seperti yang disebutkan oleh Prinsloo dan McMenemy, menunjukkan bahwa program literasi adalah praktik sosial yang disebut juga sebagai inklusi sosial (Chowdhury et al., 2008; Prinsloo, 2013). (4) Karakteristik pembelajar. Dalam proses pengembangan literasi, pustakawan perlu memahami karakter pembelajar yang berbeda-beda, mulai dari latar belakang sosial dan eknominya, tingkat pendidikan, usia, suku bangsa dan budaya, serta pengalaman hidup. Dalam karakter ini, proses perlu menekankan usia, karena semakin tua usia seseorang, individu tersebut akan semakin sulit menerima proses pembelajaran. Penurunan kemampuan kognisi mempengaruhi cara berpikir dan daya nalar, termasuk kekuatan memori yang dibutuhkan untuk menghubungkan berbagai konteks yang diperlukan untuk pemahaman. Selain itu, pemustaka dengan disfabilitas membutuhkan penanganan khusus yang perlu dipelajari oleh pustakawan. 
Bila penerapan literasi diterapkan secara efektif dan memadai, maka kemampuan dasar literasi tersebut akan menghasilkan kompetensi yang dibutuhkan, yaitu berpikir kritis dan kreatif, dan mampu berkomunikasi dan bekerjasama dengan baik (World Economic Forum, 2015). Dengan demikian, tujuan pembelajaran sepanjang hayat dapat tercapai, yaitu menghasilkan individu yang memiliki karakter berkualitas.

Secara singkat, untuk memudahkan penerapan literasi, pustakawan pertamatama menentukan kompetensi yang diinginkan, kemudian menentukan kualitas karakternya. Setelah itu, pustakawan dapat menentukan jenis literasinya. Langkahlangkah tersebut digunakan sebagai dasar pembuatan program yang akan dilaksanakan agar terarah, sistematis, efektif, dan efisien.

\section{Penerapan program-program}

literasi di atas dapat dikembangkan berdasarkan kebutuhan dan kebijakan masing-masing perpustakaan. Perpustakaan perlu melibatkan orangtua pemustaka anak dan berbagai lembaga terkait. Yang penting adalah melakukan penerapan dengan menekankan proses, sehingga pustakawan dan pemustaka dapat saling belajar satu sama lain (Browne \& McMenemy, 2010: 19). Berikut ini kegiatan yang menekankan proses yang dapat dilakukan oleh perpustakaan untuk meningkatkan imajinasi, baik dengan buku maupun dengan alat permainan: a. bacakan buku dan mendongeng, b. ciptakan suasana yang aman dan menyenangkan, c. bebaskan dan bereksperimen, d. bermain peran

\section{KESIMPULAN DAN SARAN}

Strategi perpustakaan menerapkan literasi di Indonesia masih dalam tahap menumbuhkan minat dan gemar membaca, belum mampu menumbuhkan imajinasi, kreativitas, dan inovasi. Straetegi yang dilakukan oleh kebanyakan perpustakaan masih berorientasi pada pemenuhan administratif perpustakaan atau lembaga induknya. Keberhasilan gerakan literasi masih diukur dari jumlah koleksi yang dibaca pemustaka atau jumlah pemustaka yang membaca buku dalam kurun waktu tertentu, padahal seharusnya keberhasilan diukur dari munculnya daya imajinasi dan kreativitas.

Agar penerapan literasi dapat mendorong imajinasi, kreativitas, dan inovasi, berikut saran yang mungkin dapat dilakukan oleh perpustakaan: (1) Strategi yang sebelumnya hanya menyediakan fasilitas diubah dengan melakukan lebih banyak metode inklusi sosial yang menekankan interaksi personal antara pustakawan dan pemustaka. Pustakawan harus disiapkan untuk berperan aktif dan 
memahami proses pembelajaran tersebut, yang intinya harus dilakukan secara menyenangkan. Strategi ini dapat diberikan oleh para ahli, seperti ahli pedagogi dan psikolog. (2) Melakukan penelitian proses penerapan literasi dengan pendekatan kualitatif. Pendekatan ini tidak bertujuan mengukur seperti penelitian literasi yang banyak menggunakan kuantitatif, melainkan bertujuan menemukan makna di dalam praktik penerapan literasi. Temuan dari jenis penelitian ini diharapkan mampu mengungkapkan pemahaman proses literasi, atau proses belajar, dalam masyarakat terkait, sehingga dapat diambil solusi terbaik.

\section{DAFTAR PUSTAKA}

American Library Association. (2009). ALA's Core Competences of Librarianship. Retrieved February 20, 2019, from http://www.ala.org/ educationcareers/sites/

Chowdhury, G. ., Burton, P. F., McMenemy, D., \& Poulter, A. (2008). Librarianship: an introduction. London: Facet Publishing.

Council, N. R. (2012). How Literacy Develops. In Improving Adult Literacy Instruction: Developing Reading and Writing. Washington, DC: The National Academies Press. https://doi.org/10.17226/13468

Hernelahti, S., \& Kolehmainen, S. (2014). Creative literacy as a way for multiliteracy. In Creative Commons
Attribution 3.0 Unported License (pp. 1-5). Lyon: IFLA. Retrieved from

http://creativecommons.org/licenses/ by/3.0/, on 22 February 2019

Iswari, N. (2017). Mengapa Literasi di Indonesia Sangat Terendah. Retrieved from wibhttps://student.cnnindonesia.com /edukasi/20170910122629-445240706/mengapa-literasi-diindonesia-sangat-terendah/ Retrieved by 24 Februari 2019

Jerey, B., \& Craft, A. (2004). Teaching creatively and teaching for creativity: distinctions and relationships. Educational Studiesucational Studies, 30(1), 7787.

https://doi.org/doi:10.1080/0305569 032000159750\%0A

Kemalawati, I. (2017). Upaya meningkatkan kreativitas anak melalui alat permainan balok di Taman Kanak-kanak Cipta Mulia Kecamatan Cipatat Kabupaten Bandung Barat. Empowerment, 6(1). Kementerian Pendidikan dan Kebudayaan. (2017a). MATERI PENDUKUNG LITERASI BUDAYA DAN KEWARGAAN (Gerakan Literasi Nasional). Jakarta.

Kementerian Pendidikan dan Kebudayaan. (2017b). Materi pendukung literasi numerasi (Gerakan Literasi Nasional). Jakarta.

Kementerian Pendidikan dan Kebudayaan. (2017c). MATERI PENDUKUNG LITERASI SAINS (Gerakan Literasi Nasional). Jakarta.

Min-Ying, T. (2015). The Relationships among Imagination, Future Imagination Tendency, and Future Time Perspective of Junior High 
School Students. Taiwan.

Permatasari, R. W. (2014). Penerapan metode bercerita untuk meningkatkan kreativitas pada siswa TK Kelompok B. PG-PAUD Trunojoyo, 1(1), 64-75.

Prinsloo, M. (2013). Literacy in Community Settings. In The Encyclopedia of Applied Linguistics (pp. 1-7). Blackwell Publishing Ltd. https://doi.org/10.1002/9781405198 431.wbeal0734

Rapih, S. (2016). PENDIDIKAN LITERASI KEUANGAN PADA ANAK: Mengapa dan Bagaimana? Scholaria, 6(2), 14-28.

Rooney- Browne, C., \& McMenemy, D. (2010). Public libraries as impartial spaces in a consumer society: possible, plausible, desirable? New Library World, 111(11/12), 455467.

Sugihartati, R. (2010). Membaca, gaya hidup dan kapitalisme: kajian tentang reading for pleasure dari perspektif cultural studies (Edisi Pert). Yogyakarta: Graha Ilmu.

Syaodih, E. dkk (Ed.). (2015). Membangun imajinasi dan kreativitas anak melalui literasi. In Seminar Nasional Pendidikan Dasar
SPS UPI. Jakarta: Progran Studi Pendidikan Dasar Sekolah Pascasarjana, Universitas Pendidikan Indonesia.

Thompson, N. A. (2018). Imagination and Creativity in Organizations. Organizational Creativity, Play and Entrepreneurship, 39(2-3, Special Issue), 229-250. https://doi.org/org/10.1177/0170840 617736939

Vårheim, A. (2014). Trust in Libraries and Trust in Most People: Social Capital Creation in the Public Library. The Library Quarterly. https://doi.org/10.1086/676487

Vukašinović, J. (2014). Role of knowledge in information society. Sinteza, Internet and Education, 476-479.

https://doi.org/10.15308/SINTEZA2014-476-479

Wicaksono, A. (2016). Profil Literasi Informasi Pustakawan Indonesia. Berkala Ilmu P Erpustakaan Dan Informasi, XII(1), 1-9.

World Economic Forum. (2015). New Vision for Education Unlocking the Potential of Technology. Switzerland. Retrieved from www.weforum.org 